\title{
Comparison of the long-term efficacy between entecavir and tenofovir in treatment- naïve chronic hepatitis $B$ patients
}

Ji Won Park ${ }^{1,2}$, Kyeong Min Kwak ${ }^{3,4}$, Sung Eun Kim ${ }^{1}$, Myoung Kuk Jang ${ }^{5}$, Ki Tae Suk ${ }^{6}$, Dong Joon Kim ${ }^{6}$, Sang Hoon Park', Myung Seok Lee ${ }^{7}$, Hyoung Su Kim ${ }^{5 *}$ and Choong Kee Park ${ }^{1}$

\begin{abstract}
Background: There have been limited studies directly comparing the long-term efficacy between entecavir (ETV) and tenofovir disoproxil fumarate (TDF). This study was aimed to compare the long-term efficacy between them in treatment-naïve chronic hepatitis B (CHB).

Methods: Out of 345 CHB patients who received first line therapy with ETV $(n=200)$ or TDF $(n=145)$ in a cohort, 210 patients were analyzed using propensity score matching, at a ratio of 1:1.

Results: Two groups showed no difference in baseline characteristics. During the follow-up of 12 months, HBV DNA levels were similarly suppressed in both groups (ETV vs. TDF; -5.01 vs. $-5.242 \log _{10} \mathrm{lU} / \mathrm{mL}, P=0.559$ ). At month 12 , both groups showed no difference in terms of the serologic, biochemical and virologic (VR) response. In multivariate analysis, the initial virologic response at 3 months (IVR-3) was independent factor for VR at 1 year. During the long-term follow-up, HBV DNA levels were more strongly suppressed by TDF than ETV in hepatitis B e antigen (HBeAg) positive patients $(P=0.035)$, especially with high viral load $(P=0.012)$, although there was no significant difference in overall VR between two groups. The type of antivirals was not an independent factor for long-term VR.
\end{abstract}

Conclusions: Although either ETV or TDF, overall, may show a comparable long-term antiviral efficacy in treatment-naïve CHB, TDF might be better regimen than ETV in the subgroup of HBeAg-positive CHB, especially with a higher HBV DNA levels.

Keywords: Entecavir, Tenofovir, Hepatitis B virus

\section{Background}

Approximately 350 million people are estimated to be chronically infected with hepatitis B virus (HBV), which may result in serious complications, such as hepatic failure, advanced cirrhosis, and/or hepatocellular carcinoma (HCC) in $15-40 \%$ of patients [1-3]. In addition to clinical host factors, such as age, family history, and alcohol abuse, many HBV-related factors themselves, which include $\mathrm{HBV}$ mutations of precore/core promoter

\footnotetext{
* Correspondence: hskim@hallym.or.kr

${ }^{5}$ Department of Internal Medicine, Kangdong Sacred Heart Hospital of Hallym University Medical Center, 18, Cheonho-daero 173-gil, Gangdong-gu, Seoul 05355, Republic of Korea

Full list of author information is available at the end of the article
}

regions, $\mathrm{HBV}$ genotype $\mathrm{C}$, and high serum HBV DNA levels (viral factors), contribute to the critical progression of chronic liver diseases [4-6]. Although factors such as mutations or genotypes are not changed by antivirals, serum HBV DNA levels, e.g., HBV replication, can be sustainably suppressed by anti-HBV therapies to prevent and/or retard cirrhosis and subsequently HCC. To date, oral antiviral drugs such as lamivudine, adefovir, entecavir, telbivudine and tenofovir have been widely used in clinical settings $[4,7,8]$.

According to several international guidelines, entecavir (ETV) or tenofovir disoproxil fumarate (TDF) are recommended as first line therapy in the treatment of naïve $\mathrm{CHB}$ because of their higher antiviral potency and higher genetic 
barriers than other antiviral agents [9-13]. In reality, ETV and TDF showed high virologic responses of up to $93 \%$ and $100 \%$, respectively, and a rare genotypic resistance of only $1.2 \%$ and $0 \%$, respectively, during the 5 - year follow-up in a cohort study [14, 15].

Although there have been a few reports comparing the short-term efficacy directly between TDF and ETV in treatment-naïve $\mathrm{CHB}$, there is still little available clinical information about the long-term efficacy. Therefore, we performed this study to compare the long-term efficacy between TDF and ETV in treatment-naïve CHB patients.

\section{Methods}

\section{Patients and study design}

A total of 345 treatment-naïve $\mathrm{CHB}$ patients who received a single regimen of either TDF $(n=145)$ or $\operatorname{ETV}(n=200)$ for at least 12 months were consecutively enrolled from 4 tertiary university hospitals in Korea between January 2011 and December 2014. Because TDF or ETV use was not randomly assigned, potential confounding and selection biases were accounted for by developing a propensity score. Among a total of 345 patients, 210 patients were selected using propensity score match, at a ratio of 1:1. Patients with the following characteristics were excluded: 1) other viral infections such as HCV, HDV and HIV, 2) other concomitant liver diseases such as alcoholic liver disease and autoimmune liver disease, or 3) HCC. Patients were monitored by clinical examination and biochemical and virologic assessments at least every 3 to 4 months during the antiviral therapy.

The study protocol was approved by the Hallym University Medical Center Institutional Review Boards (IRB No. 13-1-49).

\section{Serum assay and methodology}

Biochemistry was performed using standard laboratory procedures. Hepatitis B surface antigen ( $\mathrm{HBsAg})$, antibody to $\mathrm{HBsAg}$ (anti-HBs), $\mathrm{HBeAg}$, and antibody to $\mathrm{HBeAg}$ (anti-HBe) were measured using microparticle enzyme immunoassay (Abbott Laboratories, North Chicago, IL, USA). Serum HBV DNA levels were measured using a COBAS TaqMan PCR assay (Roche, Branchburg, NJ, USA; lower limit of detection $20 \mathrm{IU} / \mathrm{mL}$ ).

\section{Definitions}

Primary non-response was defined as a failure to reduce serum HBV DNA levels by $>1 \log _{10} \mathrm{IU} / \mathrm{mL}$ after 3 months of therapy [16]. A high HBV DNA level was defined as a serum HBV DNA level greater than $6 \log _{10}$ $\mathrm{IU} / \mathrm{mL}$. Initial virologic response at 3 months (IVR-3) and virologic response (VR) were defined as an HBV DNA level $<3.3 \log _{10} \mathrm{IU} / \mathrm{mL}$ after 3 months of therapy $[17,18]$ and an undetectable HBV DNA level $(<20 \mathrm{IU} /$ $\mathrm{mL}$ ) during the therapy, respectively. A biochemical response was defined as a normalization of the serum alanine aminotransferase (ALT) levels. Virologic breakthrough (VBT) was defined as an increase over $1 \log _{10}$ $\mathrm{IU} / \mathrm{mL}$ of serum HBV DNA levels from the nadir during the therapy or serum HBV DNA levels $>200 \mathrm{IU} / \mathrm{mL}$ in patients who experienced VR.

\section{Statistical analyses}

HBV DNA levels were logarithmically transformed for analysis. The Mann-Whitney $U$-test for continuous variables and chi-squared test for categorical variables were used in the analyses as appropriate. A repeated measures analysis was used to compare HBV DNA reduction according to the drug used. Cumulative VR and VBT rates were calculated using the Kaplan-Meier method, and the difference was determined by a log-rank test. The multivariate logistic regression model and Cox proportional hazards model were used to identify the independent risk factors significantly associated with short-term and long-term VR, respectively. Candidate variables with a $P$ value of $<0.1$ on univariate analysis were entered into the regression analysis. A $P$-value of less than 0.05 was considered significant. Statistical analyses were performed using SPSS, version 16 (SPSS, Inc, Chicago, IL).

To reduce and control any confounding factors before receiving the treatment, we used the propensity scores to match TDF users to ETV users. A macro (available at: http://www2.sas.com/proceedings/sugi26/p214-26.pdf) was used to develop the propensity scores.

\section{Results}

\section{Baseline patient characteristics}

Among 345 patients, the propensity-matched 105 patients in each group were included (1:1). The baseline characteristics of the study population are summarized in Table 1.

One hundred thirty one (62.4\%) patients were men and the mean age was $46.2 \pm 12.0$ years. Eighty four patients (40\%) had had cirrhosis and 121 patients (57.6\%) were positive for HBeAg. The mean HBV DNA levels and ALT levels were $6.61 \pm 1.30 \log _{10} \mathrm{IU} / \mathrm{mL}$ and $205.9 \pm 351.5 \mathrm{IU} /$ $\mathrm{L}$, respectively. There was no difference in the baseline characteristics between the TDF and ETV groups. On average, patients were treated for 25.3 (12-39) months.

\section{Therapeutic responses}

Figure 1 shows the changes in the mean HBV DNA levels during the first 12 months. Overall, serum HBV DNA levels continuously declined, and the overall mean changes at months 3,6 and 12 were $-4.26 \log _{10} \mathrm{IU} / \mathrm{mL}$, $-4.89 \log _{10} \mathrm{IU} / \mathrm{mL}$ and $-5.12 \log _{10} \mathrm{IU} / \mathrm{mL}$, respectively (Fig. 1a). The mean reduction in serum HBV DNA levels from baseline to month 12 was similar in the ETV and TDF groups ( -5.01 vs. $\left.-5.22 \log _{10} \mathrm{IU} / \mathrm{mL}, P=0.559\right)$ using a repeated measure analysis (Fig. 1b). During the first year 
Table 1 Baseline characteristics of the patients

\begin{tabular}{llll}
\hline Variables & $\begin{array}{l}\text { ETV } \\
(n=105)\end{array}$ & $\begin{array}{l}\text { TDF } \\
(n=105)\end{array}$ & $P$ \\
\hline Age (years) & $47.0 \pm 12.0$ & $45.5 \pm 11.9$ & 0.396 \\
Sex (male, \%) & $64(61.0)$ & $67(63.8)$ & 0.776 \\
HBeAg-positive (\%) & $58(55.2)$ & $63(50.0)$ & 0.577 \\
$\begin{array}{l}\text { Disease status; } \\
\text { CHB/LC (\%) }\end{array}$ & $62 / 43$ & $64 / 41$ & 0.888 \\
$\begin{array}{l}\text { MELD } \\
\text { (<7/7-13/>13, \%) }\end{array}$ & $(59.0 / 41.0)$ & $(61.0 / 39.0)$ & \\
Serum ALT (IU/L) & $(69.5 / 24.8 / 5.7)$ & $71 / 33 / 1$ & 0.800 \\
$\begin{array}{l}\text { Serum total } \\
\text { bilirubin (mg/dL) }\end{array}$ & $179.5 \pm 253.0$ & $232.3 \pm 427.4 / 1.0)$ & 0.278 \\
$\begin{array}{l}\text { Serum albumin (g/dL) } \\
\text { INR }\end{array}$ & $4.11 \pm 0.56$ & $4.10 \pm 0.53$ & 0.905 \\
$\begin{array}{l}\text { Serum HBV DNA level } \\
\text { (log } 10 \text { IU/mL) }\end{array}$ & $1.12 \pm 0.19$ & $1.11 \pm 0.17$ & 0.927 \\
$\begin{array}{l}\text { Duration of follow-up } \\
\text { (months) }\end{array}$ & $27.0 \pm 7.2$ & $1.06 \pm 1.29$ & 0.507 \\
\hline
\end{tabular}

Continuous variables were expressed as mean \pm standard deviation $A L T$ alanine aminotransferase, $C H B$ chronic hepatitis $B, E T V$ entecavir, $H B e A g$ hepatitis $B$ e antigen, $H B V$ hepatitis $B$ virus, INR international normalized ratio, $L C$ liver cirrhosis, MELD model for end stage liver disease, TDF tenofovir

of therapy, VR (HBV DNA levels $<20 \mathrm{IU} / \mathrm{mL}$ ) and primary non-response were observed in 161 (76.7\%) and 0 patients $(0 \%)$, respectively. One hundred fifty of 184 patients who had shown elevated serum ALT levels at baseline achieved a normalization of serum ALT levels (81.5\%). During the first year of therapy, HBeAg loss/seroconversion occurred in 18 of 121 (14.9\%) HBeAg-positive patients.

There were no significant differences in the virologic, serologic and biochemical responses at year 1 between two groups (Table 2). The mean reduction in serum HBV DNA levels from baseline to month 12 was similar between the ETV and TDF groups ( -5.54 vs. $-5.78 \log _{10}$ $\mathrm{IU} / \mathrm{mL}, P=0.159)$, even in the $\mathrm{HBeAg}$-positive patients
(Fig. 2a). Although HBV DNA levels were more strongly suppressed by TDF than by ETV ( -5.92 vs. $-5.78 \log _{10}$ $\mathrm{IU} / \mathrm{mL}, P=0.022)$ in the HBeAg-positive subgroup with higher HBV DNA levels (Fig. 2b), the type of antiviral used was not an independent factor for VR. During the mean long-term therapy period of 25.3 months, the virologic and serologic responses were additionally achieved in 22 and 10 patients, respectively. Persistent viremia was observed in 26 patients, consisting of 17 patients $(16.2 \%, 17 / 105)$ in the ETV group and 9 patients $(8.6 \%$, $9 / 105)$ in the TDF group.

The cumulative VR rates at 3, 6, 12, 24 and 36 months were $20 \%, 54 \%, 79 \%, 86 \%$ and $91 \%$, respectively, during the follow-up period (Fig. 3a). The cumulative VR rates in the ETV group at 3, 6, 12, 24 and 36 months were $21 \%, 55 \%$, $75 \%, 84 \%$ and $87 \%$, respectively, whereas, in the TDF group, the rates at $3,6,12,24$ and 36 months were $19 \%, 52 \%, 83 \%$, $91 \%$ and $94 \%$, respectively. These differences were not significant (Fig. $3 \mathrm{~b}, P=0.222$ ). The cumulative VR rates in the HBeAg-negative subgroup also showed no significant difference between the ETV and TDF groups (89\%, 96\% and $100 \%$ vs. $76 \%, 98 \%$ and $100 \%$ at 6,12 and 24 months, respectively, $P=0.819$ ). However, in the $\mathrm{HBeAg}$-positive subgroup, the cumulative VR rates in the ETV group at 6, 12,24 and 36 months were $28 \%, 57 \%, 70 \%$ and $77 \%$, respectively, whereas the rates in the TDF group at $6,12,24$ and 36 months were $37 \%, 73 \%, 84 \%$ and $91 \%$, respectively, with significant difference between two groups $(P=0.035$, Fig. 3c). This finding was conspicuous in another subgroup of HBeAg-positive CHB with higher HBV DNA levels $(20 \%, 53 \%, 68 \%$ and $68 \%$ at $6,12,24$ and 36 months in ETV group vs. $32 \%, 71 \%, 83 \%$ and $90 \%$ at $6,12,24$ and 36 months in TDF group, respectively, $P=0.012$, Fig. $3 \mathrm{~d}$ ).

\section{Predictive factors for virologic response}

A multivariate logistic regression model was used to identify the independent risk factors significantly associated
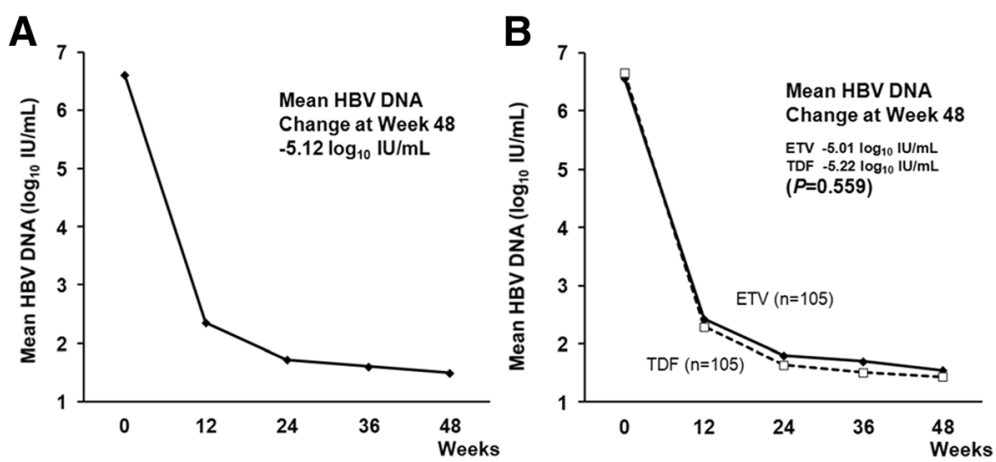

Fig. 1 Change of HBV DNA during follow-up period. a The changes in the mean hepatitis B virus (HBV) DNA levels from baseline through week 48. The overall mean changes at weeks 12,24 and 48 were $-4.26 \log _{10} \mathrm{IU} / \mathrm{mL},-4.89 \log _{10} \mathrm{IU} / \mathrm{mL}$ and $-5.12 \log _{10} \mathrm{IU} / \mathrm{mL}$, respectively. $\mathbf{b}$ The $\mathrm{mean}$ reduction in serum HBV DNA levels from baseline to week 48 was similar in tenofovir and entecavir group $\left(-5.22 \mathrm{vs} .-5.01 \mathrm{log}{ }_{10} \mathrm{IU} / \mathrm{mL}, P=0.559\right)$ by repeated measure analysis 
Table 2 Virologic, serologic and biochemical response at week 48

\begin{tabular}{|c|c|c|c|c|c|}
\hline & Baseline & Week 24 & Week 48 & Total & $P$ \\
\hline Mean HBV DNA $\left(\log _{10} \mathrm{IU} / \mathrm{mL}\right)$ & 6.61 & 1.72 & 1.49 & $5.12 \downarrow$ & 0.559 \\
\hline $\operatorname{ETV}(n=105)$ & 6.56 & 1.80 & 1.55 & $5.01 \downarrow$ & \\
\hline TDF $(n=105)$ & 6.66 & 1.64 & 1.44 & $5.22 \downarrow$ & \\
\hline HBV DNA negativity by PCR & & & & $161(76.7 \%)$ & 0.192 \\
\hline $\operatorname{ETV}(n=105)$ & & $58(55.2 \%)$ & $76(72.4 \%)$ & & \\
\hline $\operatorname{TDF}(n=105)$ & & $56(53.3 \%)$ & $85(81.0 \%)$ & & \\
\hline HBeAg loss/seroconversion & & & & $18(14.9 \%)$ & 0.452 \\
\hline $\operatorname{ETV}(n=58)$ & & & $7(12.1 \%)$ & & \\
\hline $\operatorname{TDF}(n=63)$ & & & $11(17.5 \%)$ & & \\
\hline Biochemical response & & & & $150(81.5 \%)$ & 0.647 \\
\hline $\operatorname{ETV}(n=92)$ & & & 77 (83.7\%) & & \\
\hline $\operatorname{TDF}(n=92)$ & & & $73(79.3 \%)$ & & \\
\hline
\end{tabular}

Data are expressed mean or number

ETV entecavir, $H B e A g$ hepatitis B e antigen, HBV hepatitis B virus, TDF tenofovir

with VR during the first year. In a univariate analysis, disease status (CHB vs. cirrhosis), HBeAg status, serum HBV DNA levels and IVR-3 were candidate variables for the multivariate analysis. Of the clinical features, cirrhosis, HBeAg negativity, low serum HBV DNA levels and IVR-3 were considered favorable factors for VR, while other factors, including the type of antiviral used (ETV vs. TDF), were not significantly associated with VR (Table 3). In the multivariate analysis, only IVR-3 remained independent predictors for one year VR (Table 4).

A cox proportional hazards model was used to identify the independent factors for long-term VR. In the multivariate analysis, HBeAg status, serum HBV DNA levels and IVR-3 were identified as predictive factors for longterm VR (Table 5).

\section{Predictive factors on the long-term efficacy}

Sixty seven patients (31.9\%) had low baseline serum HBV DNA levels $\left(<6 \log _{10} \mathrm{IU} / \mathrm{mL}\right), 173$ patients $(82.4 \%)$ showed IVR-3 and 89 patients (42.4\%) were negative for HBeAg. The patients with low serum HBV DNA levels, IVR-3 or HBeAg negativity had a significantly higher probability of achieving a VR. In patients with low baseline serum HBV DNA levels, the cumulative VR rates were $84 \%, 94 \%, 97 \%$ and $100 \%$ at $6,12,24$ and 36 months, which were in contrast with the rates, $40 \%, 72 \%, 80 \%$ and $83 \%$ in patients with high baseline serum HBV DNA levels $(P<0.001$, Fig. 4 a). The cumulative VR rates were $64 \%, 89 \%, 94 \%$ and $100 \%$ in patients with IVR-3 and 5\%, 32\%, $46 \%$ and $51 \%$ in patients without IVR-3 at $6,12,24$ and 36 months, respectively $(P<0.001$, Fig. $4 \mathrm{~b})$. A similar pattern was observed according to $\mathrm{HBeAg}$ status $(P<0.001)$.
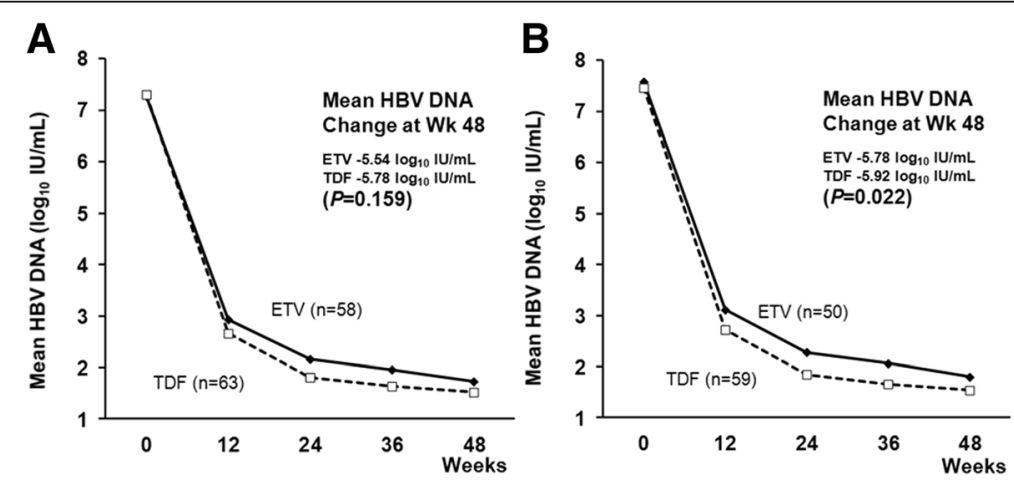

Fig. 2 Change of HBV DNA in HBeAg-positive patients. a The mean reduction in serum hepatitis B virus (HBV) DNA levels from baseline to month 12 was similar in tenofovir and entecavir group ( $-5.88 \mathrm{vs}$. $\left.-5.54 \log _{10} \mathrm{IU} / \mathrm{mL}, P=0.159\right)$ in the hepatitis e antigen (HBeAg) positive patients. $\mathbf{b}$ Serum HBV DNA levels were more strongly suppressed by tenofovir than entecavir ( $\left.-5.92 \mathrm{vs} .-5.78 \log _{10} \mathrm{IU} / \mathrm{mL}, P=0.022\right)$ in the HBeAg-positive patients with a higher HBV DNA levels 


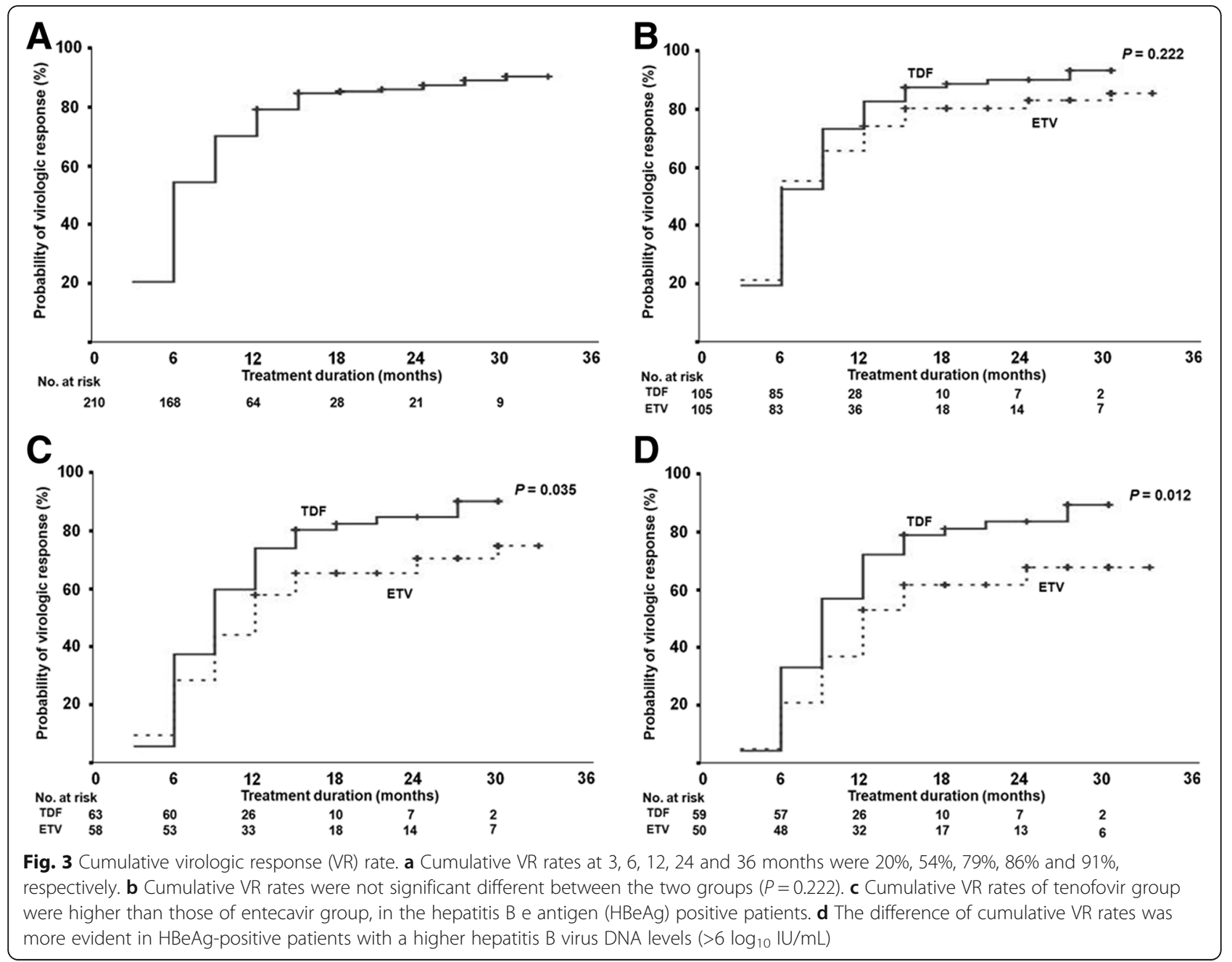

\section{Virologic breakthrough during long-term therapy}

VBT was experienced in 13 patients, with cumulative rates of $1 \%, 4 \%$ and $11 \%$ at 12,24 and 36 months, respectively. There was no significant difference in the cumulative rates between the ETV and TDF groups (2\%, $5 \%$ and $12 \%$ vs. $1 \%, 4 \%$ and $7 \%$ at 12,24 and 36 months, respectively, $P=0.333$ ). VBT developed in 9 cases in the ETV group and in 4 cases in the TDF group. The majority $(11 / 13,85 \%)$ of VBT was related to medication adherence. As expected, mutations associated with drug resistance were detected in 2 patients in the ETV group (L180M+ M204V + S202G).

\section{Adverse effects}

No serious adverse effects such as lactic acidosis or increase in serum creatinine levels were reported in any of the patients in either treatment group. No adverse effects leading to discontinuation of therapy occurred during the whole treatment period. During the follow-up period, 6 patients $(5.7 \%)$ in TDF group and $7(6.7 \%)$ in ETV group were diagnosed with HCC. The incidence of
HCC according to the type of treatment was not different. All of them except two patients were already cirrhotic patients before antiviral treatment, the patients diagnosed with HCC were significantly older than without $\mathrm{HCC}$ at the beginning of antiviral treatment (54.2 \pm 8.5 vs. $45.7 \pm 12.0, P=0.014$ ).

\section{Discussion}

The risk of cirrhosis and/or HCC in CHB increases proportionally as serum HBV DNA levels increase $[5,6]$. This finding suggests that sustained suppression of HBV replication with anti-HBV therapy may successfully prevent the progression of chronic liver diseases. Thus, the suppression of HBV replication should be considered the most important therapeutic goal for $\mathrm{CHB}$ patients in clinical settings. Currently, ETV and TDF are the most commonly used HBV drugs due to their excellent potency and higher genetic barrier. However, there is limited information on the comparative efficacy of these drugs, and only one drug-to-drug comparison study has been conducted thus far [19]. Although there have been, 
Table 3 Comparison of clinical features between the groups according to one year virologic response

\begin{tabular}{|c|c|c|c|}
\hline Variables & $\begin{array}{l}\text { Patients with VR } \\
(n=161)\end{array}$ & $\begin{array}{l}\text { Patients without VR } \\
(n=49)\end{array}$ & $P$ \\
\hline Age (years) & $46.8 \pm 11.0$ & $44.4 \pm 14.7$ & 0.285 \\
\hline Sex (male, \%) & $99(61.5)$ & $32(65.3)$ & 0.737 \\
\hline HBeAg-positive (\%) & $77(47.8)$ & $44(89.8)$ & $<0.001$ \\
\hline $\begin{array}{l}\text { Disease status; } \\
\text { CHB/LC (\%) }\end{array}$ & $\begin{array}{l}85 / 76 \\
(52.8 / 47.2)\end{array}$ & $\begin{array}{l}41 / 8 \\
(83.7 / 16.3)\end{array}$ & $<0.001$ \\
\hline $\operatorname{MELD}(<7 / 7-13 />13, \%)$ & $\begin{array}{l}109 / 47 / 5 \\
(67.7 / 29.2 / 3.1)\end{array}$ & $\begin{array}{l}35 / 12 / 2 \\
(71.4 / 24.5 / 4.1)\end{array}$ & 0.768 \\
\hline Serum ALT (IU/L) & $198.0 \pm 305.7$ & $231.8 \pm 475.0$ & 0.557 \\
\hline Serum total bilirubin (mg/dL) & $1.12 \pm 1.46$ & $1.19 \pm 1.77$ & 0.774 \\
\hline Serum albumin(g/dL) & $4.10 \pm 0.53$ & $4.11 \pm 0.60$ & 0.952 \\
\hline INR & $1.12 \pm 0.17$ & $1.09 \pm 0.21$ & 0.319 \\
\hline IVR-3 (-/+) & $12 / 149(7.5 / 92.5)$ & $25 / 24(51.0 / 49.0)$ & $<0.001$ \\
\hline Serum HBV DNA level $\left(\log _{10} \mathrm{IU} / \mathrm{mL}\right)$ & $6.30 \pm 1.23$ & $7.61 \pm 0.97$ & $<0.001$ \\
\hline Treatment regimens & & & 0.192 \\
\hline $\operatorname{ETV}(n=105, \%)$ & $76(72.4)$ & $29(27.6)$ & \\
\hline $\operatorname{TDF}(n=105, \%)$ & $85(81.0)$ & $20(19.0)$ & \\
\hline
\end{tabular}

Data are expressed as mean \pm standard deviation or number

ALT alanine aminotransferase, CHB chronic hepatitis B, ETV entecavir, HBeAg hepatitis B e antigen, $H B V$ hepatitis $\mathrm{B}$ virus, INR international normalized ratio, IVR-3 initial virologic response at 3 months, $L C$ liver cirrhosis, MELD model for end stage liver disease, TDF tenofovir, VR virologic response

so far, a few studies evaluating the efficacy of ETV and TDF in treatment-naïve CHB, they included only a limited number of patients or only showed a short-term efficacy [20-25]. Futhermore, most previous studies were retrospective and not randomized, some of them showed different baseline characteristics-such as age, gender or liver disease severity. The present study was also not a randomized controlled trial, but the limitation was complemented by using propensity score. The present study enrolled an adequate number of the treatment-naïve CHB patients and followed these patients for a sufficient time period (up to 39 months) to directly compare the efficacy between ETV and TDF. Of note, in this study, the majority of patients had a VR over $90 \%$ after 36 months of therapy. Among HBeAg-positive patients, the cumulative VR rates at month 12 in our study $(75 \%$ in ETV and 83\% in TDF) are comparable with previous global multicenter trials of $67 \%$ and $76 \%$, respectively. These results were also comparable in $\mathrm{HBeAg}$-negative

Table 4 Multivariate analyses of clinical factors affecting one year virologic response

\begin{tabular}{llll}
\hline Factors & $\mathrm{RR}$ & $95 \% \mathrm{Cl}$ & $P$ \\
\hline Disease status $(\mathrm{CHB} / \mathrm{LC})$ & 0.559 & $0.205-1.521$ & 0.255 \\
IVR-3 $(+/-)$ & 6.214 & $2.500-15.443$ & $<0.001$ \\
HBeAg $(-/+)$ & 3.184 & $0.977-10.377$ & 0.055 \\
Serum HBV DNA level $\left(\log _{10} \mathrm{IU} / \mathrm{mL}\right)$ & 0.605 & $0.357-1.023$ & 0.061 \\
\hline
\end{tabular}

$R R$, relative risk, $95 \% \mathrm{Cl} 95 \%$ confidence interval, $C H B$ chronic hepatitis $\mathrm{B}$, $H B e A g$ hepatitis $B$ e antigen, $H B V$ hepatitis $B$ virus, IVR-3 initial virologic response at 3 months, LC liver cirrhosis patients (97\% vs. $90 \%$ in ETV; $98 \%$ vs. $93 \%$ in TDF, respectively) $[9,10,12]$.

In this study, ETV and TDF showed similar overall antiviral efficacy both for one year and during the long-term follow-up. These results were similar to previous studies [21-23, 25]. However, our subgroup analysis indicated that TDF was significantly better than ETV for suppressing HBV DNA in HBeAg-positive patients, especially with higher HBV DNA levels. There were a few studies which TDF showed more potent antiviral efficacy than ETV in HBeAgpositive patients $[24,26]$. When comparing our study with these previous studies, the present study included only treatment-naïve patients and who had been adherent to medication therapy for at least one year. Patient adherence may contribute to achieve comparable overall VR at month 12 and during long-term period in both groups.

Another interesting finding in the present study is the prognostic role of IVR-3, which is a good predictive factor for both short-term and long-term VR. Higher baseline ALT, lower HBV DNA levels and HBeAg-negative status are already well known to be associated with VR. In addition to these factors, our finding suggested that IVR-3 was also able to predict VR very well. In fact, cumulative VR rates in patients achieving IVR-3 was significantly higher than in patients without IVR-3 $(100 \%$ vs. $51 \%$ at 36 months, RR 3.403, 95\% CI 1.977-5.849, $P<0.001$ ). Surprisingly, the predictive value of IVR-3 was much higher than those of previously known factors, such as HBeAg status and HBV DNA levels. Pragmatically, IVR-3 combined with $\mathrm{HBeAg}$ and HBV DNA levels may help to predict 
Table 5 Factors associated with long-term virologic response

\begin{tabular}{|c|c|c|c|c|c|c|}
\hline \multirow[t]{2}{*}{ Factors } & \multicolumn{3}{|c|}{ Univariate analysis } & \multicolumn{3}{|c|}{ Multivariate analysis } \\
\hline & $\mathrm{RR}$ & $95 \% \mathrm{Cl}$ & $P$ & $\mathrm{RR}$ & $95 \% \mathrm{Cl}$ & $P$ \\
\hline Age (years) & 1.007 & $0.995-1.018$ & 0.262 & & & \\
\hline Sex (female/male) & 1.009 & $0.747-1.363$ & 0.952 & & & \\
\hline HBeAg-positive $(-/+)$ & 3.031 & $2.209-4.158$ & $<0.001$ & 1.834 & $1.246-2.698$ & 0.002 \\
\hline Disease status (LC/CHB) & 1.577 & $1.172-2.121$ & 0.003 & 1.028 & $0.748-1.411$ & 0.867 \\
\hline $\operatorname{MELD}(<7 / \geq 7)$ & 0.923 & $0.676-1.260$ & 0.613 & & & \\
\hline INR & 1.020 & $0.469-2.218$ & 0.961 & & & \\
\hline Serum ALT (IU/L) & 1.000 & $1.000-1.000$ & 0.890 & & & \\
\hline Serum total bilirubin (mg/dL) & 1.005 & $0.918-1.101$ & 0.908 & & & \\
\hline Serum albumin (g/dL) & 1.077 & $0.824-1.406$ & 0.588 & & & \\
\hline IVR-3 (+/-) & 4.851 & $2.902-8.109$ & $<0.001$ & 3.403 & $1.977-5.859$ & $<0.001$ \\
\hline $\begin{array}{l}\text { Serum HBV DNA level } \\
\left(\log _{10} \mathrm{IU} / \mathrm{mL}\right)\end{array}$ & 0.638 & $0.569-0.715$ & $<0.001$ & 0.817 & $0.696-0.958$ & 0.013 \\
\hline Therapy regimens (TDF/ETV) & 1.162 & $0.868-1.555$ & 0.313 & & & \\
\hline
\end{tabular}

$R R$ relative risk, 95\% $C I$ 95\% confidence interval, $A L T$ alanine aminotransferase, $C H B$ chronic hepatitis $\mathrm{B}, E T V$ entecavir, $H B e A g$ hepatitis $\mathrm{B}$ e antigen, $H B V$ hepatitis $\mathrm{B}$ virus, INR international normalized ratio, IVR-3 initial virologic response at 3 months, LC liver cirrhosis, MELD model for end stage liver disease, TDF tenofovir

long-term VR and determine whether to maintain primary therapy or switch to other regimens.

Multi-center, long-term studies using ETV and/or TDF have shown excellent safety and tolerance with little antiviral resistance (1.2\% in ETV and $0 \%$ in TDF up to 5 years). In our study, there was no serious clinical adverse reaction in the two treatment groups. However, even though the patient had achieved VR, HCC was developed in $5.7 \%$ of patients receiving TDF and $6.7 \%$ of ETV. Considering the risk of developing $\mathrm{HCC}$ is appears to be greatest among individuals with the highest serum HBV DNA levels, the introduction of nucleos $(\mathrm{t})$ ide analogues has contributed to reduce the risk of $\mathrm{HCC}$. The reason why the incidence of HCC was higher than previous studies was that the present study included a large number of cirrhotic patients. Cirrhosis has been well known risk factor for HCC. Actually, all patients diagnosed with $\mathrm{HCC}$ in this study were cirrhotic patients, except two patients. Our finding confirmed that old and cirrhotic patients should be carefully undergone surveillance for $\mathrm{HCC}$ regardless of achieving VR.

It should be considered that poor medication adherence is a major cause of suboptimal response and/or VBT that tends to be increasingly prevalent in proportion to the duration of therapy [27-31]. In the current study, overall cumulative VBT rates were $1 \%, 4 \%$ and $11 \%$ at 12,24 and 36 months, respectively, which was primarily related to medication adherence. Only two patients showed resistance in the ETV group.

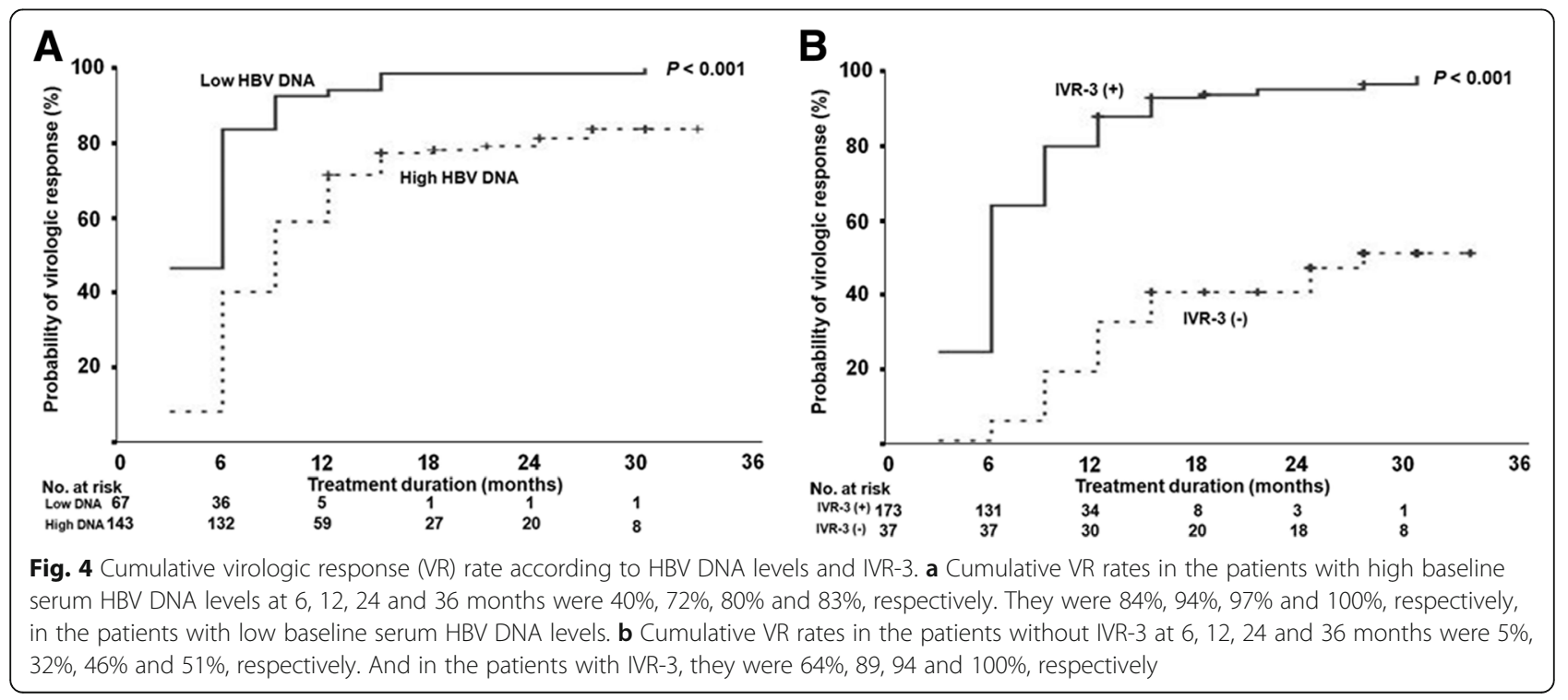


Our study has some limitations. First, the study was retrospective and non-randomized. However, we adjusted this shortcoming by using propensity score to minimize the influence of the baseline characteristics. This process made our outcomes to be more reliable. Second, in the process of matching the patients, the sample size was decreased and the follow-up period was shortened. Nevertheless, each group included over 100 patients and the follow-up period was up to 39 months. This is comparable with the most recently published, randomized controlled trial to compare treatment efficacy of ETV and TDF in treatment-naïve $\mathrm{CHB}$ patients [32]. Third, the study may not be generalizable to other ethnic groups because we included only Asian patients (Koreans) who were infected by mainly HBV genotype $C$.

To date, randomized controlled or well matched comparative studies regarding the efficacy of TDF or ETV in treatment-naive $\mathrm{CHB}$ patients were very rare. Therefore, it is necessary to conduct direct comparisons of a prospective nature with larger numbers of patients and longer period of treatment.

\section{Conclusions}

TDF and ETV showed comparable efficacy and safety during 3 years in treatment-naïve CHB patients. We found that IVR-3 was predictive factor on long-term efficacy in addition to HBV DNA levels and HBeAg status. The present study suggested that TDF might be the more potent option in a subgroup of $\mathrm{HBeAg-positive} \mathrm{CHB}$, especially with higher HBV DNA levels. VBT occurred with similar rates in both groups, and was primarily the result of medication nonadherence. Old and cirrhotic patients should be carefully undergone surveillance for HCC regardless of achieving VR.

\section{Abbreviation}

ALT: Alanine aminotransferase; anti-HBe: Antibody to hepatitis B e antigen; anti-HBs: Antibody to hepatitis B surface antigen; CHB: Chronic hepatitis B; ETV: Entecavir; HBeAg: Hepatitis B e antigen; HBsAg: Hepatitis B surface antigen; HBV: Hepatitis B virus; HCC: Hepatocellular carcinoma; IVR-3: Initial virologic response at 3 months; TDF: Tenofovir; VBT: Virologic breakthrough; VR: Virologic response

\section{Acknowledgments}

Not Applicable.

\section{Funding}

The authors who have taken part in this study declare that they do not have anything to disclose regarding funding. No grants or financial support were received for this study.

\section{Availability of data and materials}

The datasets during the current study are available from corresponding author on reasonable request.

\section{Authors' contributions}

HSK, DJK and CKP designed the study. JWP, SEK, MSL, SHP and KTS carried out the extraction of data. KMK, MKJ and HSK carried out the statistical analysis of studies. JWP wrote the paper. All authors read and approved the final manuscript.

\section{Competing interests}

The authors declare that they have no competing interests.
Consent for publication

Not Applicable.

\section{Ethics approval and consent to participate}

The study protocol was approved by the Hallym University Medical Center Institutional Review Boards (IRB No. 13-1-49). The ethical committee waived the need for a written informed consent because this study was performed retrospectively.

\section{Publisher's note}

Springer Nature remains neutral with regard to jurisdictional claims in published maps and institutional affiliations.

\section{Author details}

${ }^{1}$ Department of Internal Medicine, Hallym University Sacred Heart Hospital of Hallym University Medical Center, 22, Gwanpyeong-ro 170 beon-gil, Dongan-gu, Anyang-si, Gyeonggi-do 14068, Republic of Korea. ${ }^{2}$ Department of Biomedical Gerontology, Graduate School of Hallym University, 1 Hallymdaehak-gil, Chuncheon-si, Gangwon-do 24252, Republic of Korea. ${ }^{3}$ Department of Occupational and Environmental Medicine, Hallym University Sacred Heart Hospital of Hallym University Medical Center, 22, Gwanpyeong-ro 170 beon-gil, Dongan-gu, Anyang-si, Gyeonggi-do 14068, Republic of Korea. ${ }^{4}$ Department of Environmental Health, Seoul National University School of Public Health, 1, Gwanak-ro, Gwanak-gu, Seoul 08826, Republic of Korea. ${ }^{5}$ Department of Internal Medicine, Kangdong Sacred Heart Hospital of Hallym University Medical Center, 18, Cheonho-daero 173-gil, Gangdong-gu, Seoul 05355, Republic of Korea. ${ }^{6}$ Department of Internal Medicine, Chuncheon Sacred Heart Hospital of Hallym University Medical Center, 77, Sakju-ro, Chuncheon-si, Gangwon-do 24253, Republic of Korea. ${ }^{7}$ Department of Internal Medicine, Kangnam Sacred Heart Hospital of Hallym University Medical Center, 1, Singil-ro, Yeongdeungpo-gu, Seoul 07441, Republic of Korea.

Received: 29 September 2016 Accepted: 1 March 2017

Published online: 09 March 2017

\section{References}

1. Safileas M, Lyqidakis NJ, Manti C. Hepatitis B today. Hepatogastroenterology. 2007:54:545-8.

2. Lavanchy D. Hepatitis B, virus epidemiology, disease burden, treatment, and current and emerging prevention and control measures. J Viral Hepat. 2004;11:97-107.

3. Bosch FX, Ribes J, Cleries R, Diaz M. Epidemiology of hepatocellular carcinoma. Clin Liver Dis. 2005:9:191-211.

4. Lok AS, McMahon BJ. Chronic hepatitis B: update 2009. Hepatology. 2009;50:661-2.

5. Chen CJ, Yang HI, Su J, Jen CL, You SL, Lu SN, et al. Risk of hepatocellular carcinoma across a biological gradient of serum hepatitis B virus DNA level. JAMA. 2006;295:65-73.

6. Hoeje UH, Yang HI, Su J, Jen CL, You SL, Chen CJ. Predicting cirrhosis risk based on the level of circulating hepatitis B viral load. Gastroenterology. 2006:130:678-86.

7. Liaw YF. Hepatitis B, virus replication and liver disease progression: the impact of antiviral therapy. Antivir Ther. 2006;11:669-79.

8. Chang TT, Liaw YF, Wu SS, Schiff E, Han KH, Lai CL, et al. Long-term entecavir therapy results in the reversal of fibrosis/cirrhosis and continued histological improvement in patients with chronic hepatitis B. Hepatology. 2010;52:886-93.

9. Chang TT, Gish RG, de Man R, Gadano A, Sollano J, Chao YC, et al. A comparison of entecavir and lamivudine for HBeAg-positive chronic hepatitis B. N Engl J Med. 2006;354:1001-10.

10. Lai CL, Shouval D, Lok AS, Chang TT, Cheinguer H, Goodman Z, et al. Entecavir versus lamivudine for patients with $\mathrm{HBeAg}$-negative chronic hepatitis B. N Engl J Med. 2006:354:1011-20.

11. Leung N, Peng CY, Hann HW, Sollano J, Lao-Tan J, Hsu CW, et al. Early hepatitis $B$ virus DNA reduction in hepatitis $B$ e antigen-positive patients with chronic hepatitis B: A randomized international study of entecavir versus adefovir. Hepatology. 2009:49:72-9.

12. Marcellin P, Heathcote EJ, Buti M, Gane E, de Man RA, Krastev Z, et al. Tenofovir disoproxil fumarate versus adefovir dipivoxil for chronic hepatitis B. N Engl J Med. 2008;359:2442-55. 
13. European Association for the Study of the Liver. EASL clinical practice guidelines: management of chronic hepatitis B virus infection. J Hepatol. 2012;57:167-85.

14. Tenney DJ, Rose RE, Baldick CJ, Pokornowski KA, Eggers BJ, Fang J, et al. Long-term monitoring shows hepatitis $B$ virus resistance to entecavir in nucleoside-naive patients is rare through 5 years of therapy. Hepatology. 2009;49:1503-14.

15. Kitrinos KM, Corsa A, Liu Y, Flasherty J, Snow-Lampart A, Marcellin P, et al. No detectable resistance to tenofovir disoproxil fumarate after 6 years of therapy in patients with chronic hepatitis B. Hepatology. 2014;59:434-42.

16. Zoulim F, Locarnini S. Hepatitis B virus resistance to nucleos(t)ide analogues. Gastroenterology. 2009;137:1593-608.

17. Park JW, Kim HS, Seo DD, Jang JS, Shin WG, Kim KH, et al. Long-term efficacy of entecavir in adefovir-refractory chronic hepatitis B patients with prior lamivudine resistance. J Viral Hepat. 2011:18:e475-81.

18. Lee JM, Kim HJ, Park JY, Lee CK, Kim DY, Kim JK, et al. Rescue monotherapy in lamivudine-resistant hepatitis B e antigen-positive chronic hepatitis B: adefovir versus entecavir. Antivir Ther. 2009;14:705-12.

19. Murat K, Fatma S, Yesim A, Nail O, Ahmet TE, Deniz S. Head-to-head comparison of two years efficacy of entecavir and tenofovir in patients with treatment-naïve chronic hepatitis B-The real life data. Hepatogastroenterology. 2015;62:982-6.

20. Ha NB, Trinh HN, Rosenblatt L, Nghiem D, Nguyen MH. Treatment outcomes with first-line therapies with entecavir and tenofovir in treatmentnaive chronic hepatitis B patients in a routine clinical practice. J Clin Gastroenterol. 2016:50:169-74.

21. Idilman R, Gunsar F, Koruk M, Keskin O, Meral CE, Gulsen M, et al. Long-term entecavir or tenofovir disoproxil fumarate therapy in treatment-naïve chronic hepatitis B patients in the real-world setting. J Viral Hepat. 2015;22:504-10.

22. Batirel A, Guclu E, Arslan F, Kocak F, Karabay O, Ozer S, et al. Comparable efficacy of tenofovir versus entecavir and predictors of response in treatment-naïve patients with chronic hepatitis B: a multicenter real-life study. Int J Infect Dis. 2014;28:153-9.

23. Ozaras R, Mete B, Ceylan B, Ozgunes N, Gunduz A, Karaosmanoglu H, et al. First-line monotherapies of tenofovir and entecavir have comparable efficacies in hepatitis B treatment. Eur J Gastroenterol Hepatol. 2014;26:774-80.

24. Gao L, Trinh HN, Li J, Nguyen MH. Tenofovir is superior to entecavir for achieving complete viral suppression in HBeAg-positive chronic hepatitis B patients with high HBV DNA. Aliment Pharmacol Ther. 2014;39:629-37.

25. Doğan ÜB, Kara B, Gümürdülü Y, Soylu A, Akin MS. Comparison of the efficacy of tenofovir and entecavir for the treatment of nucleos(t)ide-naive patients with chronic hepatitis B. Turk J Gastroenterol. 2012;23:247-52.

26. López Centeno B, Collado Borrell R, Pérez Encinas M, Gutiérrez García ML, Sanmartin FP. Comparison of the effectiveness and renal safety of tenofovir versus entecavir in patients with chronic hepatitis B. Farm Hosp. 2016;40:279-86.

27. Hongthanakorn C, Chotiyaputta W, Oberhelman K, Fontana RJ, Marrero JA, Licari T, et al. Virological breakthrough and resistance in patients with chronic hepatitis B receiving nucleos(t)ide analogues in clinical practice. Hepatology. 2011;53:1854-63.

28. Sogni P, Carrieri MP, Fontaine H, Mallet V, Vallet-Pichard A, Trabut JB, et al. The role of adherence in virological suppression in patients receiving antiHBV analogues. Antivir Ther. 2012;17:395-400.

29. Chotiyaputta W, Hongthanakorn C, Oberhelman K, Fontana RJ, Licari T, Lok AS. Adherence to nucleos(t)ide analogues for chronic hepatitis B in clinical practice and correlation with virological breakthroughs. J Viral Hepat. 2012;19:205-12.

30. Kamezaki H, Kanda T, Arai M, Wu S, Nakamoto S, Chiba T, et al. Adherence to medication is a more important contributor to viral breakthrough in chronic hepatitis B patients treated with entecavir than in those with Lamivudine. Int J Med Sci. 2013;10:567-74.

31. Chien RN, Peng CY, Kao JH, Hu TH, Lin CC, Hu CT, et al. Higher adherence with 3-year entecavir treatment than lamivudine or telbivudine in treatment-naive Taiwanese patients with chronic hepatitis B. J Gastroenterol Hepatol. 2014;29:185-92.

32. Sriprayoon T, Mahidol C, Ungtrakul T, Chun-On P, Soonklang K, Pongpun W, et al. Efficay and safety of entecavir versus tenofovir treatment in chronic hepatitis B patients: A randomized controlled trial. Hepatol Res. 2016. doi: 10.1111/hepr.12743.

\section{Submit your next manuscript to BioMed Central and we will help you at every step:}

- We accept pre-submission inquiries

- Our selector tool helps you to find the most relevant journal

- We provide round the clock customer support

- Convenient online submission

- Thorough peer review

- Inclusion in PubMed and all major indexing services

- Maximum visibility for your research

Submit your manuscript at www.biomedcentral.com/submit

) Biomed Central 